\title{
Modernisation of railway infrastructure in the Slovak Republic
}

\author{
L. Ižvolt \& S. Hodas \\ Department of Railway Engineering and Track Management, \\ Faculty of Civil Engineering, University of Žilina, Slovak Republic
}

\begin{abstract}
This paper presents the current status and overview of ongoing and planned modernisation of the railway infrastructure in Slovakia in relation to transEuropean corridors passing through the territory of the Slovak Republic. This modernisation of railway infrastructure is supposed to increase the competitiveness of railway transport. Following the technical requirements resulting from international agreements AGC and AGTC and interoperability requirements there are characterized the current and future trends in design and technological processes of modernisation of the main railway corridors for the operation of train sets at the speed $160 \mathrm{~km} \cdot \mathrm{h}^{-1}$, capable of operation even for the train sets with tilting units up to $200 \mathrm{~km} \cdot \mathrm{h}^{-1}$. In the second part, some realized and planned investments which are the part of the railway infrastructure in the Slovak Republic will be characterized, such as the marshalling yard ŽilinaTeplička, in operation since 2012, as well as localization and dispositions of planned intermodal transport terminals.

Keywords: railway infrastructure, track modernisation, construction, software support, track, marshalling yard, intermodal transport terminal.
\end{abstract}

\section{Introduction}

The railway infrastructure in the area of Slovakia (hereinafter referred to as SR) has been developing for more than 170 years in various economic, political and strategic conditions. The present infrastructure can be characterized as an infrastructure with:

- relatively dense network of railway tracks and stations,

- very good accessibility of passenger and freight transport to the main agglomerations and industries, 
- sufficient network capacity,

- good connection to the adjacent railway infrastructure of the E.U., including an important connection to the international corridors and international waterways.

Until 31.12.2011 the basic capacity of the railway infrastructure of the Slovak Railways company (hereinafter referred to as ŽSR) was formed by the rail tracks of overall length $3622 \mathrm{~km}$ (including $2607 \mathrm{~km}$ of single-track and $1015 \mathrm{~km}$ double-track line and multi-track lines). There are $3473 \mathrm{~km}$ of standard gauge tracks, $99 \mathrm{~km}$ [1] of wide gauge tracks [2] and $50 \mathrm{~km}$ of narrow gauge tracks, which include 65 independent stations, 248 dependent stations and 479 stops altogether. The overall number of turnouts under ŽSR administration is 8544, and there are 2285 bridges, 504 of them are made of steel. The overall length of tunnels is approximately $43.5 \mathrm{~km}$; the overall number of tunnels 76 comprises 69 single-track and 7 double track tunnels. Almost half of the number of railway crossings which is 2219 is formed by unsecured crossings. The present state of the railway infrastructure can be seen in fig. 1 .

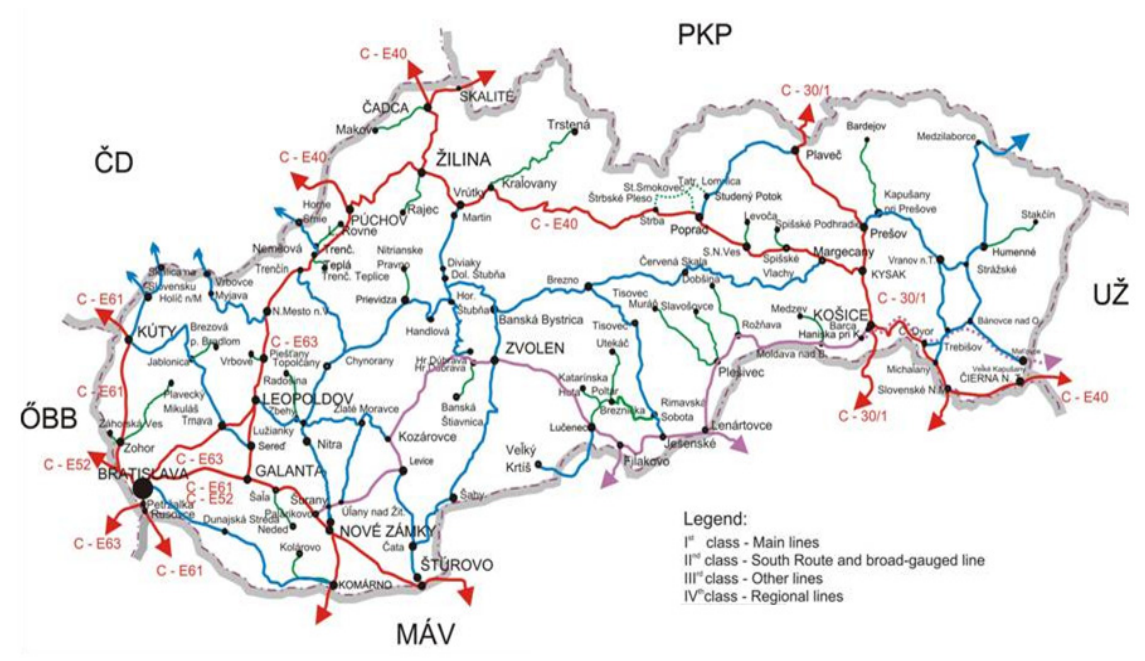

Figure 1: $\quad$ Present state of railway infrastructure in Slovakia [1].

Unfortunately, the development of the railway infrastructure of ŽSR significantly lags behind many European countries. It is necessary the state pays closer attention to this problem. At the same time, it is desirable to reassess the existing railway infrastructure in relation to the E.U. priorities in the field of railway transport. Subsequently, it is necessary to divert the funds to the tracks that are of high importance not only to the economy and mobility of the Slovak Republic but also the Community, especially the TEN-T network tracks. Although the present SR railway infrastructure is extensive, it is not very efficient and attractive, with: 
- gradually degrading parameters (speed, axial load, lengths of passing tracks in the stations, limiting structure gauge for exceptional consignments, technically outdated safety equipment),

- insufficient level of electrification $(43,5 \%)$ and a non-electrified main route so called southern route (Bratislava - Zvolen - Fil'akovo - Košice) - one of two main routes,

- constant decrease of the connections to industry-sidings, their absence in some new logistical and industrial centres and their termination in the existing ones (more than $80 \%$ of all goods start or terminate their journey on sidings),

- the lack of ability to operatively meet the needs of customers. Even despite the decrease of charges since 1.1.2011 (of passenger transport in approximately $10 \%$ and freight transport in approximately $50 \%$ ) and the introduction of toll charges to road transport, the railway transport remains economically unattractive for business as it is still 1.5 to 2 times costlier.

The transport policy of the E.U, presented by the White Paper, and the subsequent legislative activities focus on the support of railway transport and the increase of its competitiveness against other means of transport. This is understandable as railway transport is one of the safest and most environmentfriendly transport systems. Reinforcing the safety of railway transport alongside with the railway interoperability are the pillars of the forming European integrated railway area. From this point of view it is a duty of ŽSR to implement its strategic investment plans and positively influence the transportation policy of the state in a way the railway transport could become an important tool of solving the transportation relations in the area of SR.

\section{Requirements for modernisation of railway tracks in SR}

The modernisation of railway infrastructure in the area of SR aligns with and relates to the E.U. transport policy, attempting at benefiting from its relatively favourable geographical position and includes its main railway tracks into the defined European railway corridors. These corridors were gradually shaped at three pan-European conferences in Prague (1991), in the Crete (1994) and in Helsinki (1997) and their networks is formed by 9 railway and road corridors, while the tenth one, labelled VII, is the Danube waterway.

The Slovak railway network is a part of several important European corridors (corridors AGC, AGTC, TEN-T), and these are (fig. 2):

- corridor no. $I V$ - Dresden - Praha - Bratislava/Wien - Budapest-Arad (+ branches) (including the track Komárno - Nové Zámky, as a part of the freight corridor $\mathrm{E}$ ),

- corridor no. $V$ - Venezia - Trieste/Koper - Ljublana - Budapest - Čop Lvov; with the branch $\mathrm{Va}$, passing through the Slovak territory with the section Bratislava - Žilina - Košice - Čierna n.Tisou - Čop as a corridor Va,

- corridor no.VI - Gdańsk - Warszawa - Katowice - Zwardoń/Čadca - Žilina (branches Bielsko Biała-Ostrava-Břeclav), 
- TEN-T no. 17 - Paris - Strassbourg - Stuttgart - Wien - Bratislava (ŽSR part ÖBB Kittsee/Bratislava-Petržalka - node Bratislava, ÖBB Marcheg/ŽSR Devínska Nová Ves),

- TEN-T no. 23 - Gdańsk - Warszawa - Brno/Bratislava (Zwardoń PKP/ŽSR Skalité - Čadca - Žilina - Nové Mesto nad Váhom), corridor E - Dresden Prague - Wien/Bratislava - Budapest.

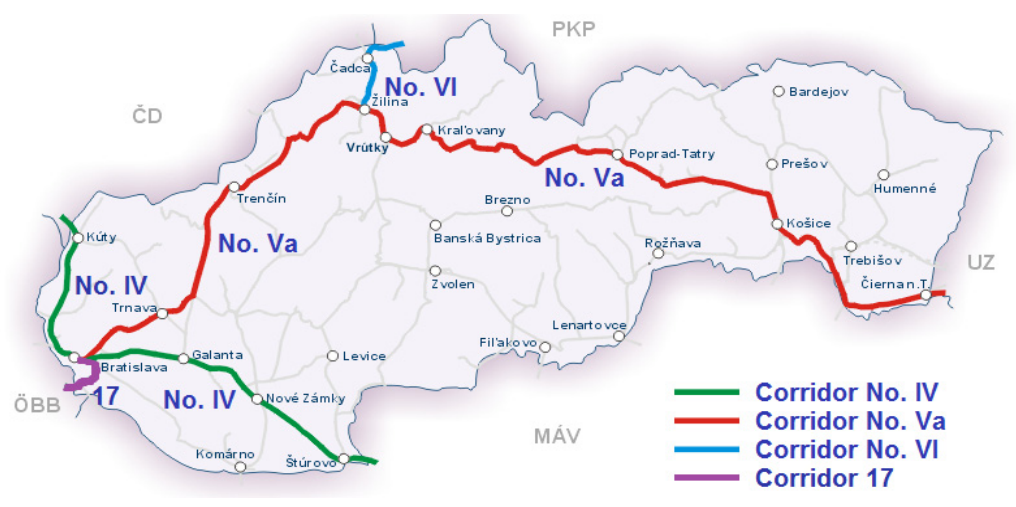

Figure 2: Corridors passing through the area of the Slovak Republic [1].

The preparation of modernisation of international railway corridors in the Slovak railways started in 1994. The aim of the modernisation of railway tracks in the Slovak territory is not only to reach their required technical level, characteristic for the European railways of the $21^{\text {st }}$ century but also to enable a better accessibility to the trans-European transport network and the transport networks of the neighbouring states. However, the comfort (stricter requirements for the geometric position of tracks, planned reconstructions of station buildings, construction of platforms of sufficient length with a barrier-free access, employment of modern train sets, etc.) and operational safety (removal of level crossings, modernisation of safety equipment) have to be enhanced as well.

The modernisation of ŽSR railway tracks is realized according to [3] and includes:

- complex reconstruction of railway substructure and superstructure including all the bridges and culverts,

- incorporation of platforms on all the railway stations and stops on the modernised track sections; the platforms of the railway stations are always placed in a way that the platform edge is at the first passing track, so the platform edge is located at the height of $550 \mathrm{~mm}$ above the rail head surface. They are in the stations where the express trains of the length of $400 \mathrm{~m}$ may stop and at stops where the passenger trains of the length $250 \mathrm{~m}$ may stop. The construction of level access to platforms is also planned.

- increase of the turnout layout penetrability by installing the slim turnouts; at the turnout layouts of a modernised station there is always at least one "fast" railway crossover located between the main tracks, while the turnouts in the 
track crossover and the connected turnouts for the branch tracks in the common turnout layout are designed for the same speed in the diverging branch, at least $80 \mathrm{~km} \cdot \mathrm{h}^{-1}$,

- completely new safety equipment and communication equipment, reconstruction of power supply stations, switching stations and TV,

- in order to increase the safety of railway operation the level crossings are being replaced with grade separated crossings,

- in the places where the noise levels do not meet the given limits, the noise walls are being built.

As a result of increasing the speeds to $160 \mathrm{~km} \cdot \mathrm{h}^{-1}\left(200 \mathrm{~km} \cdot \mathrm{h}^{-1}\right)$, high standards are set to the geometric position of railway tracks (direction and height ratios, track layout) of the modernised tracks. The present tracks do not often meet these requirements and the routes are often led on new track beds and only in partial sections they follow the original track axis. In many cases it is necessary to relocate the existing roads or waterways. Considering the geographical conditions of Slovakia, tunnel routing and the construction of new tunnels is not unusual. The latest tunnel of ŽSR tracks was built in 1966.

The modernisation of corridor tracks also involves complex reconstruction of catenaries - the change of power supply system from DC $(3 \mathrm{kV})$ to $\mathrm{AC}(25 \mathrm{kV})$. The concerned heavy current distributions and electric lighting are also being reconstructed; electric turnout heating is being installed. Naturally, the modernised tracks are also equipped with modern telecommunication technology - new telecommunication systems for data transmission and digitization of the entire railway communication network.

An important feature of modernised ŽSR tracks are noise related measures. To eliminate the negative effects of noise on people and the track surrounding, the noise maps are already constructed in the stage of project preparation. In case of unsatisfactory noise levels of equivalent noise level $\Delta L_{A e}$ anti-noise measures are proposed, most frequently noise walls (PHS).

\section{Overview of completed structures of ŽSR railway infrastructure modernisation}

When we assess the present state of the ŽSR railway modernisation, it is necessary to point out that the progress of railway infrastructure modernisation shows a considerable time lag. This can be demonstrated by the fact that the initial plan of works at the ŽSR corridor track modernisation stated the work completion in 2010. Meanwhile, the modernisation plan has had to be updated and adapted several times due to various, primarily financial reasons.

Until the end of 2011 in the Slovak territory, $92 \mathrm{~km}$ of railway tracks on the corridor Va (Bratislava-Rača - Nové Mesto nad Váhom), $18.9 \mathrm{~km}$ on the corridor no.VI (Žilina - Krásno nad Kysucou) were modernised, including all the stations and stops on these tracks. The platformization in the railway stations Poprad and Prešov and the revitalization of the marshalling yard Žilina-Teplička were also completed. 
The first structure of the railway infrastructure modernisation in the ŽSR network was the modernisation of the double-track line Bratislava-Rača Trnava, located on the corridor Va that was realized from 2006 to 2007. The preparation and project works started in 1994. The beginnings were relatively difficult as it was the first structure and the designers and the investor needed to gain a lot of experience. The most discussed issues were the track speed (the change from $140 \mathrm{~km} \cdot \mathrm{h}^{-1}$ to $160 \mathrm{~km} \cdot \mathrm{h}^{-1}$ ), the number of variants, axial distances not only in stations but also e.g. on bridges, the employment of electronic safety equipment (ESE), as well as the way of commissioning of the structure. The structure consisted of 3 interstational sections, namely:

- Bratislava-Rača - Šenkvice $(19.460 \mathrm{~km})$, completed in 2006 ,

- Šenkvice - Cífer (11.280 km), completed in 2007 and

- Cífer - Trnava $(9.910 \mathrm{~km})$, completed in 2007.

The most important structure was so called railway flyover Šenkvice. The Šenkvice relocation that included this flyover is located on the track section ŽST Pezinok - ŽST Šenkvice. The concerned track section is led on the track relocation that is largely formed by embankment, up to $8 \mathrm{~m}$ high, and the substantial part of relocation is formed by railway flyover that is $753 \mathrm{~m}$ long. The bridge structure from pre-stressed concrete, $753 \mathrm{~m}$ long, is a unique structure on Slovak railway tracks.

The modernisation of the track Trnava - Nové Mesto nad Váhom in the section ŽST Trnava - ŽST Piešt'any started in 2004 and was completed in 2008 [4]. It was divided into track sections:

- Trnava - Piešt'any $(32.950 \mathrm{~km})$ and

- Piešt'any - Nové Mesto nad Váhom (19.980 km).

The most complicated part of the construction was the reconstruction of ŽST Leopoldov, which is an important railway node in the region (fig. 3).

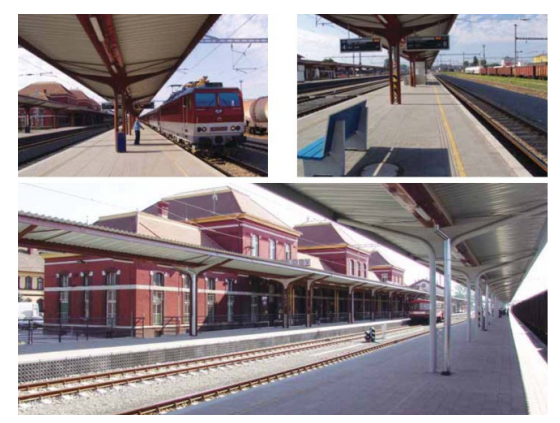

Figure 3: $\quad$ Modernised ŽST Leopoldov.

The modernisation of the track section Piešt'any - Nové Mesto nad Váhom was divided into 5 parts, two of them were ŽST Piešt'any and ŽST Nové Mesto nad Váhom (fig. 4) and the other 2 were line sections between stations. 


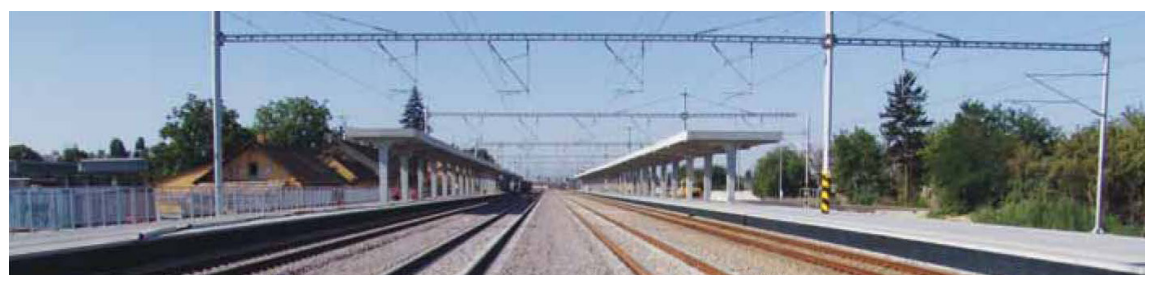

Figure 4: $\quad$ Modernised ŽST Nové Mesto nad Váhom [5].

In 2007 the construction of platforms at ŽST Prešov and ŽST Poprad-Tatry was completed and from 2008 to 2011 a part of the corridor no. VI in section Žilina - Krásno nad Kysucou (11.326 km) was modernised.

In 2009-2011 the marshalling yard Žilina-Teplička was renovated, or in other words, completed. Its construction started in 1976 on the basis of results of various research tasks and studies worked out from 1960s to 1980s. The construction of the marshalling yard was originally divided into 5 constructions with the assumed completion deadline in 1992. The completion deadline was not met and the construction was left unfinished with only vaguely definable extent of realized, partially built (unfinished) and only planned structures and operational building complex. Practically, only after the year 2000 some more serious discussions about the marshalling yard Žilina-Teplička started again. In 2004, a tender was called for projects of providing the project preparation of the structure "ŽSR, Žilina-Teplička - marshalling yard, $2^{\text {nd }}$ structure, $2^{\text {nd }}$ stage". The renovation of the marshalling yard itself started on July, 1, 2009 and was completed at the end of 2011. It was realized in the scope that is demonstrated by fig. 5 and for the planned capacity of 1200 railcars in 24 hours. At present the reception group has 6 running tracks of average effective length approx. $900 \mathrm{~m}$, 3 handling sidings and 1 dead-end siding. The sorting group has 18 tracks of effective length 805 to $880 \mathrm{~m}$ and an engine siding. On all the sorting sidings the hydraulic track brakes of PHB 04 type are fitted. The departure group has 5 running tracks of effective length 800 to $1000 \mathrm{~m}$. The realization of the transit group was not performed within this project (it was put into operation in 1978).

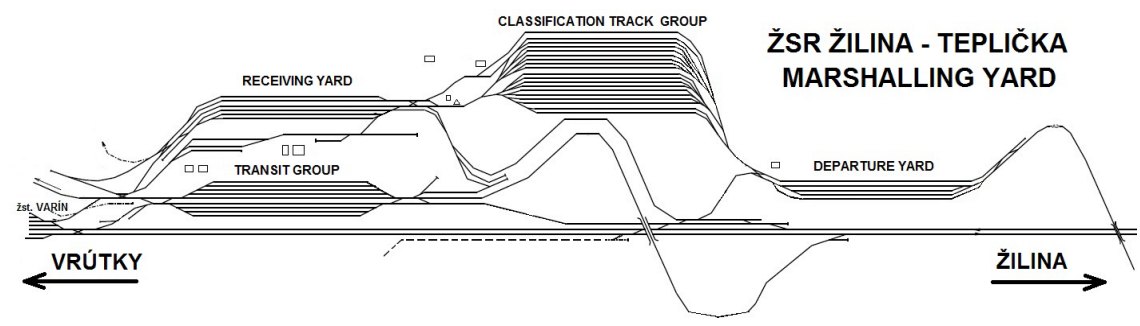

Figure 5: $\quad$ Structure renovation - scope of reconstruction works.

A present, in relation to the Program of Modernisation and Development of Railway Infrastructure for 2011 to 2014, which was approved by the Slovak 
government in $10 / 2010$, the preparation or realization of several structures within the modernisation of Slovak railway infrastructure is in progress. On the basis of this plan, in 2011-2014 another $56.8 \mathrm{~km}$ of tracks will be built and in 2015 another $30.2 \mathrm{~km}$. The steps of the modernisation of the corridor nova, no. VI and TEN-T 17, including the financial costs for their realization are given by fig. 6 .

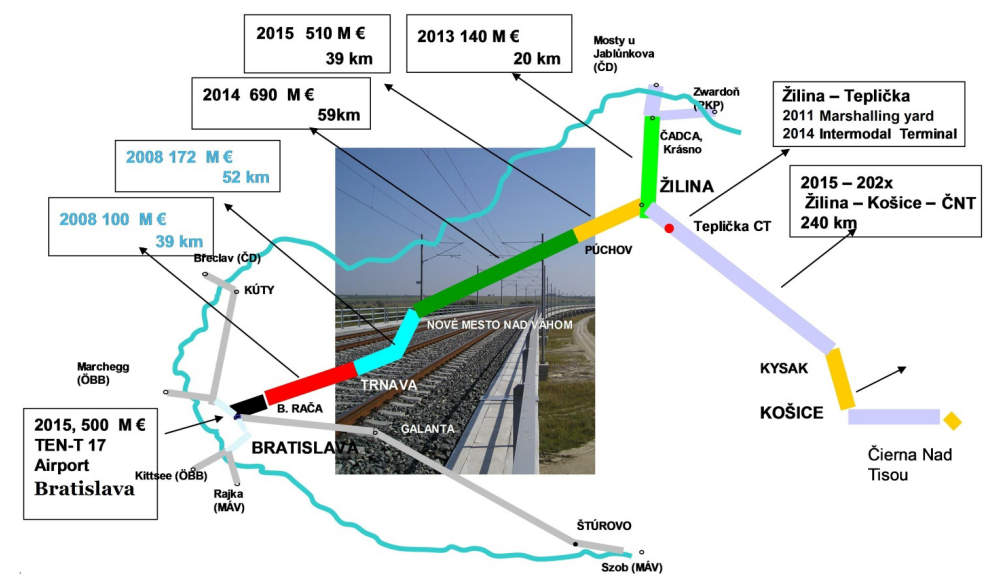

Figure 6: Plan of modernisation of the corridors no. Va and VI [6].

The track section of the corridor between ŽST Nové Mesto nad Váhom and ŽST Púchov is supposed to be completed by 2014. The construction is divided into 6 stages:

- Nové Mesto nad Váhom - Zlatovce $-1^{\text {st }}$ and $2^{\text {nd }}$ stage,

- Zlatovce - Trenčianska Teplá $-3^{\text {rd }}$ stage,

- Trenčianska Teplá - Beluša $-4^{\text {th }}$ and $5^{\text {th }}$ stage,

- Beluša - Púchov $-6^{\text {th }}$ stage.

The section Nové Mesto nad Váhom - Zlatovce will undergo the modernisation of $17.475 \mathrm{~km}$ of railway track. The construction works started on 29.9.2009 and the work completion is planned for May 2013. The works are divided into 2 stages. The first stage is formed by the section Nové Mesto nad Váhom - Trenčianske Bohuslavice, that consists of the modernisation of the ŽST Trenčianske Bohuslavice, where on the turnout layout of Žilina direction the first crossover from turnouts of 1:26.5-2500 on ŽSR tracks is fitted, and there is also a double-track tunnel under Turecký vrch mountain and the construction of first ever section with the solid track on ŽSR tracks - in the tunnel and on its glacis.

The plans for construction of the tunnel Turecký vrch [7], which overall length in the axis is $1775 \mathrm{~m}$, started 45 years ago.

The direction ratios of the track in the tunnel are designed for the speed 200 $\mathrm{km} \cdot \mathrm{h}^{-1}$ and are formed by 2 opposing arches of the radius $2000 \mathrm{~m}$ with a straight interline that is $573 \mathrm{~m}$ long. In all the length (including the portal sections) there is a uniform cross-section of the double-track tunnel with the light radius of the 
tunnel tube $6.10 \mathrm{~m}$ and with the axial distance of the tracks $4.20 \mathrm{~m}$, (one of track in operation since 13.07.2012).

Due to the decrease of the mining works area and also due to durability and fixed position of the railway track or its minimal maintenance in operation, the solid track of type RHEDA 2000 was chosen as a railway superstructure. It is also placed in the parts of the track in front of the both portals (fig. 7).

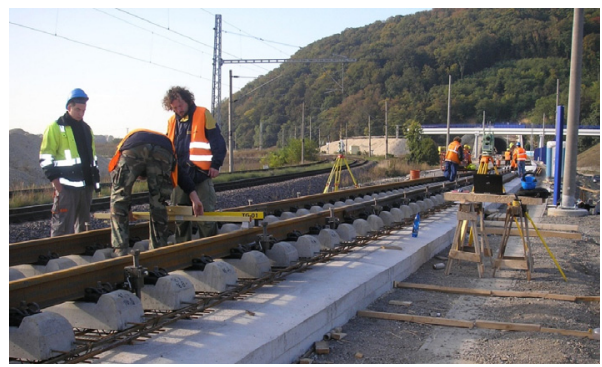

Figure 7: The tunnel Turecký vrch under construction with the view of the solid railroad RHEDA 2000 being built.

The second stage consists of the modernisation of the railway stations Trenčianske Bohuslavice and Melčice, of 2 interstational sections Trenčianske Bohuslavice - Melčice and Melčice - Zlatovce and of Kostolná-Záriečie (fig. 8).

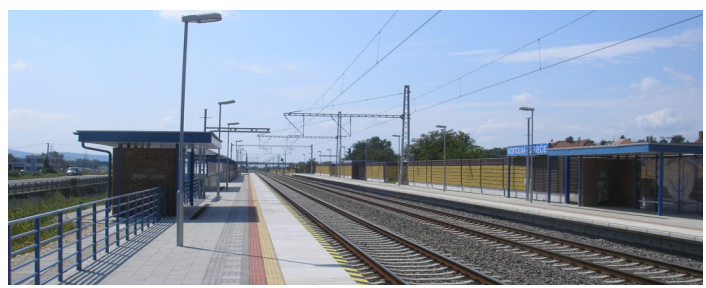

Figure 8: Railway stop Kostolná-Záriečie.

The section Zlatovce - Trenčianska Teplá ( $3^{\text {rd }}$ stage) involves modernisation of $11.952 \mathrm{~km}$ of railway track. The interstational section between Zlatovce and Trenčín is formed by the new ferroconcrete railway bridge over the river Váh, $360 \mathrm{~m}$ long, which was designed to reach the required speed $140 \mathrm{~km} \cdot \mathrm{h}^{-1}$. The representation of the track routing in the vicinity of ŽST Trenčín and the visualization of the most important structures realized in this track section, are demonstrated by fig. 9 .

The section Trenčianska Teplá - Beluša $\left(4^{\text {th }}\right.$ and $5^{\text {th }}$ stage $)$ involves the modernisation of $20.409 \mathrm{~km}$ of railway track, including the railway stations Trenčianska Teplá, Dubnica, Ilava and Ladce. 

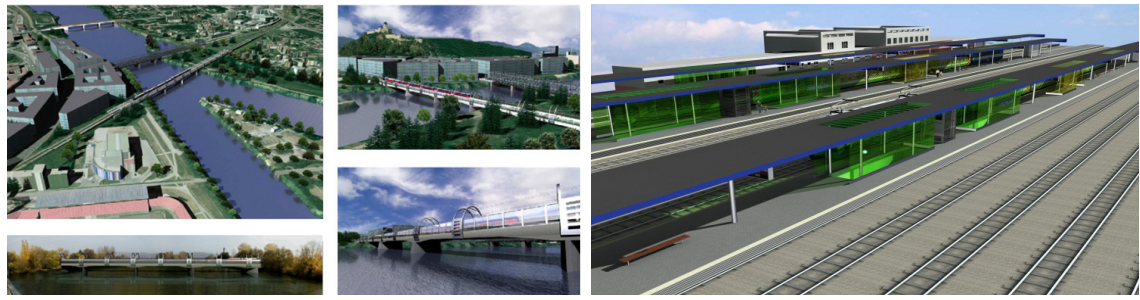

Figure 9: Routing of the modernised section in the vicinity of the future railway station Trenčín.

The section Beluša - Púchov ( $6^{\text {th }}$ stage) involves the modernisation of $7.0 \mathrm{~km}$ of railway track, including ŽST Beluša, ŽST Púchov and the railway stop Dolné Kočkovce.

The modernisation of the railway track in the section Púchov - Žilina is divided into 2 stages. The section Púchov - Považská Teplá ( $1^{\text {st }}$ stage) involves the modernisation of $15.800 \mathrm{~km}$ of railway track, including ŽST Považská Bystrica, reconstruction of the stop Nosice and the conversion of ŽST Považská Teplá to the railway stop. The track section Považská Teplá - Žilina ( $2^{\text {nd }}$ stage) involves the modernisation of $22.700 \mathrm{~km}$ of railway track and the completion of construction works is assumed for 06.2015, fig. 10 .

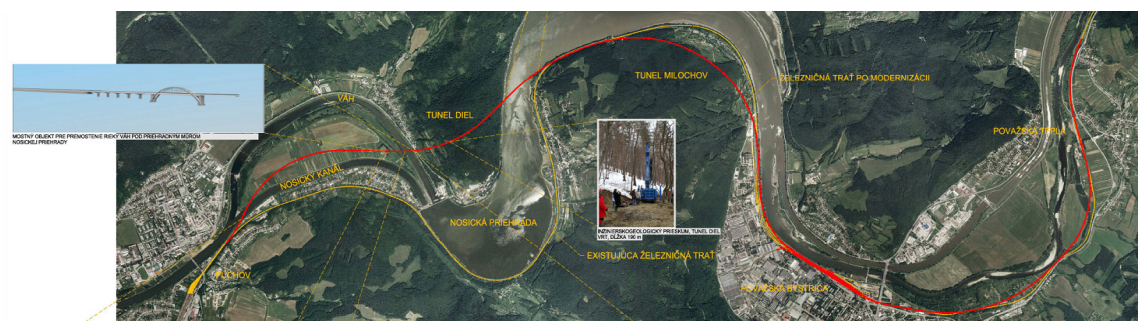

Figure 10: Modernisation design of the section Púchov - Považská Teplá.

The modernisation of the VI corridor in the section Čadca state border Čadca - Krásno nad Kysucou (the station itself does not fall into the modernisation plan) is at present in the stage of project preparation and with its length $17.1 \mathrm{~km}$ it connects to the already modernised section Žilina - Krásno nad Kysucou, which was completed in 2011.

Other sections of the Va. corridor are also being prepared as well as some other modernisation investments into railway infrastructure in the area of Slovakia. The issue of many expert discussions is the section of the corridor nova Žilina - Košice, that is basically led through a very demanding geomorphology and with regard to the present track parameters it only enables the maximum track speed of $80-100 \mathrm{~km} \cdot \mathrm{h}^{-1}$. The increase of the track speed to $160 \mathrm{~km} \cdot \mathrm{h}^{-1}$ causes that the track designed in this way largely gets off its original earthwork, it requires construction of extensive bridge and tunnel structures that 
significantly increases the investment costs for its modernisation. Concerning the section of the corridor track Va Žilina - Košice, at present only the project documentation "Modernisation of the track Liptovský Mikuláš - Košice" is being prepared. The works were divided into 4 following sections:

- Liptovský Mikuláš - Poprad (59.100 km, while approx. 67\% off its original axis),

- Poprad - Krompachy $(54.363 \mathrm{~km}$, while approx. $62 \%$ of the route off its original axis),

- Krompachy - Kysak $(45.441 \mathrm{~km}$, or $28.961 \mathrm{~km}$, while $62 \%$ off its original axis) and

- Kysak - Košice (15.262 km, while 36\% off its original axis).

"Electrification of the track Marchegg - Devínska Nová Ves" is another important investment that should contribute to the modernisation of the railway infrastructure in the Slovak territory. This project is related to the project "Interconnection of the TEN-T railway corridors and inclusion of M. R. Štefánik Airport to the railway network in Bratislava". The realization of this project could complete the existing transport network of the transport infrastructure of the Slovak capital city in the near future. It is also supposed to integrate the Slovak capital into European railway network after the construction of high speed arterial railway Paris - Strassbourg - Wien - Bratislava/Budapest.

From the point of view of increasing the importance of railway infrastructure it is necessary to build the intermodal transport infrastructure as currently in Slovakia the needed publicly accessible infrastructure for using the system of intermodal transport has not been built yet. In 2009 the PD preparation of construction of 4 terminals according to "Yellow book FIDIC - Design and Build" started. It was based on the results of the study assessing the potential of intermodal transport in Slovakia. These Public Intermodal Transport Terminals are concerned in Žilina (PITT ZA for Central Slovakia), Bratislava (PITT BA, fig. 11), Leopoldov (for Western Slovakia) and Košice (for Eastern Slovakia).

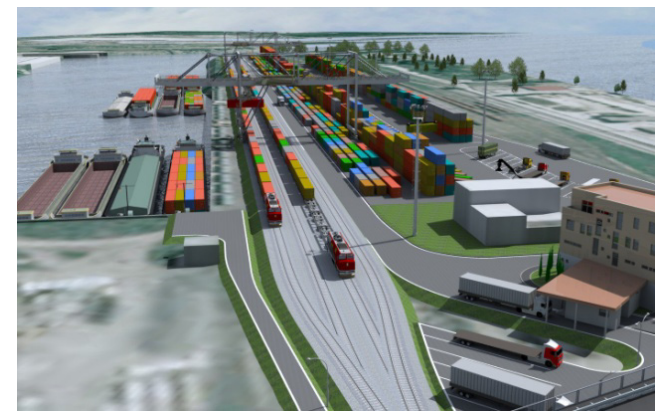

Figure 11: Visualisation of the planned PITT BA.

Besides the above mentioned projects there are many other projects that cannot be characterized due to their lesser importance and limited space for this rather long contribution. However, the corridor no. IV is worth mentioning. It is a common project with the Czech Republic. Unfortunately, because of the lack 
of finances this project named "Modernisation of the track of IV. corridor State border SR/CR - Kúty", including the new border bridge over the river Moravia, $6.9 \mathrm{~km}$ long, is at present not even in the stage of project documentation preparation.

\section{Brief characteristics of the software support for modernised tracks design}

At present it is not even thinkable to design the projects manually or in individual parts. The railway engineering requires designing in $3 \mathrm{D}$ space models from the initial stage of track design to 3D terrain model. The project is supposed to present the design completeness, where all the parties involved such as geodesists, designers and other experts bring their requirements into the designed work.

There are several options of software support available. They depend on the basic creation modules such as AutoCAD or MicroStation. These general products require special adjustments so called upgrades that are created for designing in railway engineering. For example, a great advantage is 3D processing of the terrain, direction and vertical ratios of the railway lines in AutoCAD Civil 3D by using special elements Rail07/Rail09 for designing in railway engineering. The full and complete software support is the software Ferrovia that is directly designated for railway designing, including turnouts and branches of tracks. The further option is a good quality piece of software RailCAD as a support for AutoCAD. The mentioned products are compatible.

The railway corridor is designed in space by cutting the route into the $3 \mathrm{D}$ surface (cuts, excavations, etc.) and by any further change of project design elements all the other project elements will be updated as well. The output is the final visualisation of the projects of track reconstruction and modernisation.

\section{Conclusion}

Regarding its geographical position, the Slovak Republic plays an important role in ensuring the mobility of the E.U. citizens. Providing efficient and reliable services of railway infrastructure by ŽSR depends on the existence of a powerful and interoperable railway network. However, it is possible to use this network only if its main parts that are the corridor tracks will be modernised at the same time.

It is supposed that the realized sections of the Va corridor will be completed according to the plan and at the same time the projects in the stage of project preparation will start. What we mean by this level is the quality of railway infrastructure not only from the point of view of technology but also the ability to become an attractive (safe, reliable and ecological) alternative for satisfying the transportation requirements of not only the Slovak citizens but also all the inhabitants of the common European space. 


\section{Acknowledgement}

This contribution is the result of the project implementation: "Support of Research and Development for Centre of Excellence in Transport Engineering" (ITMS: 26220120031) supported by the Research \& Development Operational Programme funded by the ERDF.

\section{References}

[1] Railways of Slovak Republic - ŽSR, http://www.zsr.sk

[2] Wide gauge track - the project is non-refundable without grant, Railway journal - Železničná revue, No. 1, http://www.reflexplus.sk/pdf/ zeleznicna revue 07.pdf, Slovak, pp. 4-6, 2011.

[3] Regulation Ž11, General principles and technical requirements for the modernised ŽSR tracks of the track gauge $1435 \mathrm{~mm}$. GR ŽSR, 02/2001.

[4] Ižvolt, L., Gocálová, Z. and Šestáková, J., Current state and plans of railway infrastructure modernisation in the Slovak. Proceedings of the Railway Infrastructure 2012: Děčín, CZ, Slovak, 2012, http://svf.uniza.sk/kzsth

[5] Doprastav, Modernisation of railway tracks 2010. Department of Mass Communications, 5/2010, http://www.doprastav.sk

[6] Maruniak, D. and Šišolák, P., Strategy of ŽSR. Modern infrastructure. Presentation on occasion of the $10^{\text {th }}$ Symposium anniversary of the establishment PSKD Society: Double Tree by Hilton Hotel, Bratislava, 2011.

[7] Nižňan, J. and Podolec, O., Conception of technical design of the tunnel Turecký vrch, Slovak. http://www.vlaky.net/zeleznice/spravy/002329Koncepcia-technickeho-riesenia-tunela-Turecky-vrch/ 